\title{
Climate change and the process of migration to Europe
}

\author{
Sebastian Paul
}

\begin{abstract}
The refugee crisis which began in 2015 showed that Europe and the EU are not prepared for the challenges of the future. Several studies are also coming to the conclusion that climate change will have a huge impact on movements of migration from Africa to Europe. By the year 2050, approximately 86 million people will be forced to flee from their country of origin as a consequence of climate change, mainly in Sub-Saharan and East Africa. Significant migration movements are expected to be the result. This paper aims to anticipate possible refugee inflows from Africa and attempts to outline a set of recommendations as to how mass migration to Europe could be avoided. For this purpose, the effects of climate change, demographic development, politics, and economics are taken into consideration with a case study on Sub-Saharan Africa. The article shows that displacement will not only affect Africa but also Europe, absent effective policy changes. However, early crisis prevention could stop mass migration to Europe. Nevertheless, climate change can only be tackled to a certain extent, and decision makers have to find ways on how to deal with this issue. Especially, urbanization programs in rural, but livable, regions could be a solution. Overall, European refugee policy has to change significantly, as the ongoing refugee crisis has the potential to disrupt European integration.
\end{abstract}

Keywords: migration, refugees, climate change, Europe, Africa, droughts, rising sea level

\section{Introduction}

The aim of this paper is to analyze migration and refugee movements to Europe as a consequence of climate change in Africa, particularly in Sub-Saharan Africa. According to the World Climate Conference 2017, there are already more "climate refugees" than

\footnotetext{
${ }^{1}$ Sebastian Paul is a PhD student at the Faculty of Social Sciences and International Relations at Corvinus University of Budapest, Hungary. His research dissertation is on the process of migration to Europe.
} 
doi: 10.14267/cojourn.2018v3n1a3

"war refugees". This issue is becoming more and more relevant - especially in light of the current refugee crisis in Europe. The research questions of this paper are: How does climate change affect the process of migration from Africa to Europe? What are the (possible) consequences of this development? And how can mass refugee movements be avoided? The link between climate change and migration is investigated on the basis of empirical data and through two case studies: Sub-Saharan Africa and East Africa, two regions significantly affected by climate change.

We can see that Africa is by far the fastest growing continent on the planet in terms of population size, while also being the continent which is most compromised by climate change, making it increasingly less habitable - issues such as sea level rise, droughts, and the underproduction of crops together adversely affect habitability. According to the World Bank, by the year 2050, approximately 140 to 150 million climate refugees will leave the African continent (World Bank, 2018). While it is true that not all of them will come to Europe, without a change in European refugee and climate policies, this development has the potential to disturb or even reverse the European integration process.

\section{Literature review}

Climate change and global warming are documented scientific facts. The evidence is overwhelming and the correlation between $\mathrm{CO}_{2}$ emissions and mean temperature cannot be interpreted in a different way. The $\mathrm{CO}_{2}$ emission level increased gradually from slightly above $310 \mathrm{ppm}$ in 1959 to above $400 \mathrm{ppm}$ in 2015 . Furthermore, the global mean temperature has also been increasing continuously, in line with the increase in $\mathrm{CO}_{2}$ emissions (EFJ, 2017: 8).

\section{Debate about numbers}

The estimations concerning future climate refugees are very different. Thus, the debate about figures is very controversial and estimates vary from 31 to 200 million climate refugees by the year 2050. One of the first researchers in this field is Norman Myers. In his research papers from 1995 and 2005, he mentioned for the first time the number of 200 million climate refugees (Myers, 1995 \& 2005) - a figure that is oft-cited in the climate debate and by NGOs. According to Myers, the main causes for migration as a consequence of environmental changes are the disruptions of monsoon systems, droughts, sea-level rise and coastal flooding. However, from the onset there was a disagreement with Myers' estimates. One of his critics is Stephen Castles from Oxford University's 
doi: 10.14267/cojourn.2018v3n1a3

International Migration Institute, who, in an interview in 2013, stated that Myers' methods are inadequate, since he assumed that every person who is affected by the rising sea-level would flee (Barnes, 2013).

Recent predictions by the World Bank in their report "Groundswell: Preparing for Internal Climate Migration" (2018) estimated that, in the worst case, there will be around 143 million climate refugees globally by the year 2050 - around 86 million from SubSaharan Africa, 40 million from South Asia, and 17 million from Latin America. Nevertheless, the World Bank has also drawn up more optimistic scenarios. In the "more inclusive development" scenario, the figures vary from 65 to 105 million refugees and the "more climate-friendly" scenario predicts between 31 and 72 million refugees. In all cases, however, the regions which will be predominantly affected by climate change are Sub-Saharan Africa, South Asia, and Latin America. Therefore, 55 percent of the developing world's population is expected to be under threat of forced displacement in the coming decades. The reasons for this are lower water availability and crop productivity and coastal areas becoming uninhabitable due to rising sea levels and storm surges. Consequently, climate sensitive sectors and infrastructure will be hit hardest by climate change, and the poorest part of the population is likely to suffer the most as a result of this (World Bank, 2018: 9-10).

A study conducted by Greenpeace and the University of Hamburg (Jakobeit and Methmann, 2007) concluded that the number of refugees who had to flee because of climate change already surpassed the amount of "official refugees" - those seeking asylum for political reasons, or who have had to flee from war. According to the study, the main indicators of climate change are droughts and limited access to water in Africa, and rising sea levels in the Pacific Ocean. Furthermore, the authors found that not only less developed regions are affected by climate change, but also highly developed regions, as Hurricane Katrina in the southern part of the United States demonstrated in 2005 (Jakob and Methmann, 2007: 26-27).

The United Nations Office for Disaster Risk Reduction (2015) reported that annually on average 21.7 million people have been displaced due to weather-related issues between 1995 and 2015. However, a database which documents forced migration caused by climate change does not currently exist. Thus, the full extent of the problem remains unclear (EFJ, 2017: 14). Nevertheless, if climate change cannot be stopped, as 
doi: 10.14267/cojourn.2018v3n1a3

many as 2 billion people might be affected by the year 2100 in one way or another (Hadlock, 2017).

\section{The legal status of climate refugees}

The Geneva Convention of 1951 does not cover climate refugees, born as it was in the context of the Second World War. Therefore, only people who are "forcibly displaced across international boundaries each year due to well-founded fear of persecution and violence" are treated as officially recognized refugees. Indeed, even if it is an important agreement on human rights, it is incapable of dealing with the climate change issue. In Europe (and the world at large), only two countries (Sweden and Finland) accept environmental refugees in principle. The UNHCR, which is usually responsible for refugees, does not have neither the required mandate or the resources to deal with the issue of climate change. Therefore, an international agreement is needed. (EFJ 2011)

\section{Demographic situation in Africa \& Europe}

Africa is the fastest growing continent. In the year 2015 the population of Africa was 1.2 billion. By the year 2050, population size is expected to double to approximately 2.5 billion people. This tremendous growth rate is expected to happen even if the fertility rates decrease significantly in the near future. Africa has the largest number of young people in the world and this will ensure that the continent will play an important role in the coming decades. At the same time, Europe's population is expected to shrink continuously over the coming decades, and by the year 2050, Europe's population size is expected to decrease by some 30 million people (UN, 2015: 1). Given this trend, the detrimental consequences of climate change are likely to be much more pronounced in Africa, especially compared to Europe with its decreasing population size.

\section{Case study: East Africa}

In the most pessimistic scenario, East Africa is going to be one of the major source regions of climate refugees in the coming decades, with some 10.1 million climate migrants by 2050. The Lake Victoria Basin, one of the biggest sources for fresh water in East Africa, is expected to become a destination for in-migration (i.e., migration to a destination within the region). Other in-migration hotspots will be the highlands of Ethiopia, Lilongwe, and the capital of Malawi. The areas which will be affected by out-migration are Kenya and Tanzania, western Uganda, and parts of the northern highlands of Ethiopia. Due to its 
doi: 10.14267/cojourn.2018v3n1a3

high population growth rates, even areas with high out-migration will see absolute increases in population size (World Bank, 2018: 79).

The population growth rate has in the past been remarkable in East Africa. Other demographic changes in East Africa are due to urbanization and internal displacement resulting from conflicts and droughts. These changes may accelerate due to further increases in population and a less habitable living space (IOM, 2015). Overall, the East African population is expected to rise from 422 million in 2010 to 676 to 786 million in by the year 2050 (World Bank, 2018: 82).

According to the World Bank, refugee hotspots will start to emerge in East Africa by the year 2030 . This trend will intensify and spread over the whole region by 2050 . The causes are deteriorating water availability and poor crop yields. In coastal regions, rising sea levels, the decreasing availability of arable land, and storm surges will be the main factors. Coastal regions are expected to lose a total of 150,000 to 750,000 people by the year 2050. Thus, people will start to move to regions which are less affected by climate change - mainly urban areas (World Bank, 2018: 84-87). Consequently, the population in urban regions will multiply from 100 million to cca. 350 to 450 million people by the year 2050. This development has already started and is mainly an effect of the rapid birth rates in East Africa. Climate change is not a factor yet but will amplify the problems in the region in the upcoming years (World Bank, 2018: 84-87).

In general, climate change will have an impact on the poor and hungry that is hard to foresee. According to the International Fund for Agricultural Development (IFAD), the Sub-Saharan region is under great risk of undernutrition, since the region is very reliant on farming. Smallholder farms, approximately 500 million of them, produce about 80 percent of the food consumed in Sub-Saharan Africa and Asia. 70 percent of the very poor live in rural regions. Therefore, they are highly dependent on agriculture and farming. Droughts and other extreme weather events will make it increasingly difficult for them to be self-sustaining (IFAD, 2011). Globally, the agricultural sector has undergone significant industrialization, but Africa has mostly remained an exception.

Less effective farming activities in countries with fragile economies and low resilience, which cannot afford farming at the highest possible standard, will result in price increases for staple foods like grains or crops (Western et al. 2015). Consequently, food insecurity and poverty will increase continually. Food supplies will no longer meet the demand, which will mostly affect the low-income part of the population. By the year 2050 , the price of maize, rice, and wheat could increase by approximately 30 to 100 
doi: 10.14267/cojourn.2018v3n1a3

percent (IFPRI, 2010: 52-84). The World Bank analyzed the impact of price shocks in terms of food and nutrition and found that 160 million people ( 90 million in rural regions) had become extremely poor and another 63 million people were malnourished in the wake of the food crises of 2008. (De Hoyos and Medvedev, 2009: 13)

The Climate Change Exposure Index (CCEI) shows that Sub-Saharan Africa is at the highest risk of changing weather patterns since 17 of the 20 countries in this area are economically very reliant on agriculture. 30 percent of the GDP is derived from the agriculture sector in countries such as Sierra Leone, Liberia, Central African Republic, Guinea-Bissau, Burundi and Rwanda. None of these countries have the capacity to adequately combat the consequences of climate change (Maplecroft, 2016). In Nigeria, Somalia, South-Sudan and Yemen, over 20 million people are starving due to food insecurity caused by droughts (EFJ, 2017: 26). However, the situation is not new in Africa. East Africa has suffered droughts in 2005, 2006, 2008, 2011, 2015, 2016 and 2017 (African Arguments, 2017). Recently, researchers found that the latest droughts are related to climate change (UNOCHA, 2017). In 2016, the food supply in the region reached a critical state - up to 24 million people were living in a state of permanent food insecurity (UNOCHA, 2016). A study from UNICEF in 2017 stated that 880,000 children were permanently undernourished and 5.5 million were in danger of hunger. This affects the state of public health as well, and the shortages in food supply, together with changes in weather patterns, are thus linked to outbreaks of yellow fever, malaria, cholera and measles (UNICEF, 2017). Overall, the following countries have been affected particularly by this crisis: Ethiopia, Kenya, Somalia, Burundi, Uganda, Djibouti, Rwanda, Sudan, South Sudan and the Democratic Republic of Congo (UNOCHA, 2016). The worst catastrophe is taking place in South Sudan. According to the UN, in 2017, as many as 100,000 people were undernourished and 1 million people died from hunger. Every seventh person had to flee due to a combination of starvation and armed conflict (UN and FAO, 2017).

Climate change intensifies political, economic, social and demographic problems, and the tensions within the society and the struggle for scarce resources, such as food supplies, or access to fresh water. This could lead to the outbreak of new conflicts, even full-blown civil wars (Burke, Hsiang and Miguel, 2015; Scheffran, 2012; PCC, 2014; Norwegian Refugee Council, 2008).

According to Harris et al. (2013), natural disasters fuel existing conflicts. Schleussner et al. (2016) found a coincidence rate of 9 percent between armed conflicts 
doi: 10.14267/cojourn.2018v3n1a3

and disasters (like heatwaves or droughts) between 1980 and 2010. In ethnically fractionalized countries, the figure was even higher, at 23 percent. Almost two-thirds of armed conflicts since 1946 have been along ethnic lines (Schleussner et al., 2016). In 2008, the increase of food prices led to riots and violence in 48 different countries (FRPI, 2014). Therefore, North and Central Africa are potential hotspots for armed conflicts in the future, since most countries in this area will suffer from climate change, and are strongly fractionized into different ethnic, religious and social groups (EFJ, 2017: 29). A study from 2009 found that climate change effects and armed conflicts in the Sub-Saharan region are highly correlated to each other. Especially in warmer years the probability for war increases significantly; this suggests that an increase in armed conflicts of more than 50 percent may be expected by 2030 (Burke, 2009). Werrell and Femina (2015), who have analyzed the Syrian conflict, pointed out the importance of climate change in the ongoing conflict on Syria as well. Climate change was not the trigger for the conflict - as it is a complex political, economic, and geopolitical battleground - but it definitely had fueled the conflict (Werrell and Femina, 2015).

\section{Discussion}

On the basis of current climate tendencies, climate change is expected to play an important role in migration from Africa to Europe. East Africa, and the Sub-Saharan region, is expected to be struck particularly hard. Indeed, more climate-friendly policies could dampen the impact global warming is set to have, but it is unlikely that the international community will be united towards an emission-free world in the near future. Thus, the question should no longer be how climate change, with all its consequences, could be prevented, but rather how to organize life to cope with it.

The key factors of the interrelated processes of climate change and population movements and some of the central observations of this paper thus are: 1) climate change exists and will lead to displacement - only the extent remains unclear; 2) climate change will affect the African continent, especially the Sub-Saharan region, very negatively; 3) the coasts and regions which will be affected by climate change will become inhabitable; 4) Africa is the fastest growing continent by population; 5) new armed conflicts and civil wars will very likely emerge in the crisis regions; 6) distribution battles for scarce 
doi: 10.14267/cojourn.2018v3n1a3

resources will result from climate change; 7) most of the displacements will happen internally, but a significant number of climate refugees will also flee to Europe.

\section{Recommendations \& challenges}

Since most of the figures in this article are estimates of future values, it may be reasonable to expect the worst-case scenario, because the measures which must be undertaken to stop forced migration to Europe would only be efficient and effective if less people are making their way to Europe than expected.

Approximately 86 million people in Africa may be forced to flee from their country of origin in the coming decades. Not all of these people would want to come to Europe, but the actual number of those choosing to attempt the journey will depend in part on the decisions of the international community in the upcoming years.

The refugee crisis of 2015 already showed that the relatively modest number of 1 to 2 million refugees from the Middle-East overwhelmed European countries and the European Union as an entity - not in terms of the financial burden, but in terms of institutional efficiency and political stability. A significantly higher number would have the potential to disturb and possibly reverse the European integration process, e.g. with a view to the Schengen Zone and related cooperation.

The Sub-Saharan region will not become completely inhabitable and some measures could even buffer the adverse effects of climate change. In order to prevent these adverse effects, huge funding programs would be required for the entire SubSaharan region; however, most of these states are struggling with political and economic issues and it might take years - at least - to build a functioning infrastructure truly suitable for increased investments in the region. One of the main problems in this context is that most of these countries have authoritarian regimes who would be not willing to cooperate with the international community, if it does not accept their conditions. Furthermore, it is very likely that a lot of money will vanish into "dark channels" (e.g. corruption). Consequently, the funding has to be for a specific purpose, or those governments which are not trustworthy should be circumvented, by providing an unconditional basic income directly to every refugee. Nevertheless, even the best funding concept cannot undo climate change. Europe has to prepare itself for a significant amount of climate refugees from the African continent, even if all recommended policy initiatives would be successful. Therefore, it is necessary to identify as early as possible the regions in Sub- 
doi: 10.14267/cojourn.2018v3n1a3

Saharan area where the effects of climate change are less profound, and which would still be able to provide sufficient living space.

In spite of international efforts, mass migration movements are set to occur from the Sub-Sahara to North Africa - another politically unstable part of the continent. One possible approach could be to rent territory for a certain period of time from other states, as the UNHCR does when renting refugee camps, but on a much bigger scale. However, political cooperation is required in order to establish well-functioning infrastructure and to meet international legal standards. The case of Nauru, an island state in the Pacific Ocean, is a good example of mismanagement and political failure in this respect. People seeking asylum in Australia are sent to Nauru, where the Australian state is operating a "processing centre." Asylum-seekers are living there under devastating conditions (e.g. water and food supply is scarce) even as Australia is spending a considerable amount of money and resources on running the centre (Doherty, 2016).

Yet the establishment of "visa/asylum centers" in North Africa, often put forward in current debates on migration as a solution, entails something similar, essentially. For this to work, the international community would have to start an urbanization process in less developed and less populated regions of North Africa - in order to make the permanent settlement of people from the Sub-Saharan region possible. In the first place, these new urban regions should be able to provide sufficient nutrition, fresh water, health care, education, cultural and even political participation, and security (including against the effects of climate change). Also, these new cities and urban regions should emerge without negatively affecting the current infrastructure and the political stability of the host country; a very difficult challenge indeed.

It is impossible to predict the exact number of climate refugees and how the EU will evolve in the approaching decades, but with the most optimistic predictions, millions of people would make their way to Europe. The South-East-European countries (Greece, Italy, and Spain) will be most affected by this influx of people. Thus, an allocation formula for the whole of the EU may still be required because none of these countries has the capacities to solve this problem without the solidarity of other EU states. Although the EU has successfully established a resettlement policy with Turkey, the situation in the EU remains unsatisfying. In total, 120,000 refugees were planned to be allocated among member states, with a view, inter alia, to their economic conditions (EC, 2017). However, in 2017, only Malta has fulfilled requirements, while other states, such as Hungary or Poland, are not accepting a single refugee (Tagesschau, 2017). In the long-run, if the rest 
doi: 10.14267/cojourn.2018v3n1a3

of the EU still resists helping in an appropriate manner, security fences and further restrictive measures may be the consequence across the continent.

The European Union needs more in the way of existing avenues for "controlled migration". As part of this, the legal status of climate refugees may also need to be clarified, as well as terms of asylum for those concerned.

\section{Conclusion}

Climate change is set to have a profound impact on humanity in the $21^{\text {st }}$ century. By 2050, millions of people may be displaced and are expected to have to flee their country of origin. The African continent will be one of the major sources of such population movements because of its geography and demography. Furthermore, economic and political developments will amplify the effects of climate change. Thus, the number of armed conflicts and civil wars may be expected to increase in the future as a consequence of struggles for resources in the affected regions. One of the consequences of this development is that more people would attempt to make their way towards Europe.

However, an early crisis prevention policy, by identifying and locating hotspots for in- and out-migration could dampen the adverse effects of climate change. Therefore, no less than an extraterritorial program of urbanization may be required to give people a viable alternative to migrating to Europe. Europe must also be prepared to accept but control better the inevitable future inflows of mass migration. One of the first steps would be the clarification of the legal status of climate refugees.

Visa and migration centers should be established in Africa in areas of permanent resettlement in order to find humanitarian solutions for asylum-seekers without giving them wrong incentives and false hopes. Otherwise, "uncontrolled" mass migration and thousands of deaths, as happened in 2015, will follow. Therefore, a shift in policy-making has to start soon in order to find appropriate solutions for the challenges involved.

\section{References}

African Arguments (2017). "Droughts in East Africa are becoming more frequent, more Devastating" [online]. Online: http://africanarguments.org/2017/03/17/droughtsin-east-africa-are-becoming-more-frequent-and-more-devastating [05.04.2018]

Burke et al. (2009). "Warming increases the risk of civil war in Africa." PNAS 106 (49), pp. 20670-20674. 
doi: 10.14267/cojourn.2018v3n1a3

Burke, M., Hsiang, S. and Miguel, E. (2015). "Climate and Conflict". Annual Review of Economics Vol. 7:577-617 (Volume publication date August 2015) [online]. Online: $\quad$ https://www.annualreviews.org/doi/10.1146/annurev-economics080614-115430

CRED - Centre for Research on the Epidemiology of Disasters. UNISDR- The United Nations Office for Disaster Risk Reduction (2015). The Human Cost of Weather Relates Disasters 1995-2015 [online]. Online: http://www.unisdr.org/2015/docs/climatechange/COP21 WeatherDisastersRepo rt_2015_FINAL.pdf [04.04.2018]

De Hoyos R.E. and Medvedev D. (2009). Poverty effects of higher food prices: a global perspective. World Bank; Washington DC: Policy Research Working Paper Series 4887 [online]. Online: http://documents.worldbank.org/curated/en/121841468333066032/pdf/ WPS4887.pdf

Doherty, B. (2016). A short history of Nauru, Australia's dumping ground for refugees [online]. The Guardian, August 10, 2016. Online: https://www.theguardian.com/world/2016/aug/10/a-short-history-of-nauruaustralias-dumping-ground-for-refugees [15.08.2018]

EC (2017). ec.europa.eu. EUROPEAN SOLIDARITY: A REFUGEE RELOCATION SYSTEM [online]. Online: https://ec.europa.eu/homeaffairs/sites/homeaffairs/files/what-we-do/policies/european-agendamigration/backgroundinformation/docs/2 eu_solidarity a refugee relocation_system_en.pdf [15.08.2018]

EFJ (2017). Environmental Justice Foundation. Beyond Borders: Our changing climate - its role in conflict and displacement [online]. Online: https://ejfoundation.org/resources/downloads/BeyondBorders.pdf [02.04.2018] EFJ (2011). EFJ Foundation. Climate Change and migration: forced displacement, 'climate refugees' and the need for a new legal instrument [online]. Online: 
doi: 10.14267/cojourn.2018v3n1a3

https://ejfoundation.org/resources/downloads/EJF climate-change-andmigration-2011.pdf [04.04.2018]

FAO (2017). 'Crisis in South Sudan' [online]. Online: http://www.fao.org/emergencies/crisis/southsudan/intro/en [05.04.2018]

Hadlock, L. (2017). Phys.org. 'Rising seas could result in 2 billion refugees by 2100' [online]. Online; https://phys.org/news/2017-06-seas-result-billion-refugees.html [15.08.2018]

Online:

https://phys.org/news/2017-06-seas-result-billionrefugees.html [04.04.2018]

Hannah Barnes (2013). BBC News. How many climate migrants will there be? [online].

Online: http://www.bbc.com/news/magazine-23899195 [03.04.2018]

Harris et al. (2013). Overseas Development Institute. Improving links between disaster resilience and conflict prevention [online]. Online: https://www.odi.org/sites/odi.org.uk/files/odi-assets/publications-opinionfiles/8228.pdf [05.04.2018]

IFAD (2011). Climate change: Building smallholder resilience [online]. Online: https://www.ifad.org/topic/resource/tags/climate change/2588644 [05.04.2018]

IFAD (2011). Rural poverty report, 2011 [online]. Online: https://www.ifad.org/documents/10180/c1bbf5fa-bdc3-4ea6-9366d163b95b1180153 [05.04.2018]

IOM (International Organization for Migration). 2015. Regional Migration Initiatives 2015.

Geneva. "GMDAC Migfacts: International Migration." [online]. Online: https://gmdac.iom.int/gmdac-migfactsinternational-migration [04.04.2018]

Jakobeit, C. \& Methmann, C. (2007). Greenpeace. Klimaflüchtlinge - die verleugnete Katastrophe [online].

Online: https://www.greenpeace.de/sites/www.greenpeace.de/files/klimafluechtlinge_en $\underline{\mathrm{dv}}$ 0.PDF $[24.03 .2018]$

Kanta Kumari Rigaud, Alex de Sherbinin, Bryan Jones, Jonas Bergmann, Viviane Clement,

Kayly Ober, Jacob Schewe, Susana Adamo, Brent McCusker, Silke Heuser, and Amelia Midgley (2018). World Bank Groundswell: Preparing for Internal Climate 
doi: 10.14267/cojourn.2018v3n1a3

Migration [online].

Online:

https://openknowledge.worldbank.org/handle/10986/29461 [24.03.2018]

Myers, N. (2005).13 ${ }^{\text {th }}$ Economic Forum, Prague. ENVIRONMENTAL REFUGEES: AN EMERGENT SECURITY ISSUE [online]. Online: https://www.osce.org/eea/14851?download=true [03.04.2018]

Myers, N. and Kent, J. (1995). Environmental Exodus: An Emergent Crisis in the Global Arena, The Climate Institute, Washington DC; and Myers, N. (2001), Environmental Refugees: Our Latest Understanding, Philosophical Transactions of the Royal Society B: 356: 16.1-16.5.

Nelson, G. C., Rosegrant, M. W., Palazzo, A., Gray, I., Ingersoll, C., Robertson, R., Tokgoz, S., Zhu, T., Sulser, T. B., Ringler, C., Msangi, S. And You, L. (2010). Food Security, Farming and Climate Change to 2050: Scenarios, Results, Policy Options. International Food Policy Research Institute (IFPRI) [online]. Online: http://ebrary.ifpri.org/utils/getfile/collection/p15738coll2/id/127066/filename/12 7277.pdf [05.04.2018]

Norwegian Refugee Council (2008). Future floods of refugees. A comment on climate change, conflict and forced migration [online]. Online: http://www.migrationdrc.org/publications/resource_guides/Migration_and_Clim ate_Change/Future floods_of_refugees.pdf [05.04.2018]

PCC (2014). Climate Change 2014: Impacts, Adaptation, and Vulnerability. Part A: Global and Sectoral Aspects. Contribution of Working Group II to the Fifth Assessment Report of the Intergovernmental Panel on Climate Change. Cambridge University Press. Online: https://www.ipcc.ch/pdf/assessmentreport/ar5/wg2/WGIIAR5-IntegrationBrochure FINAL.pdf [05.04.2018]

Scheffran, J. et al. (2012). Climate change, human security and violent conflict. Challenges for Societal Stability. Hexagon Series on Human and Environmental Security.

Schleussner et al. (2016). "Armed-conflict risks enhanced by climate-related disasters in ethnically fractionalized countries". PNAS 113 (33), pp. 9216-9221.

Tagesschau (2017). Tagesschau.de: Wie viele Flüchtlinge wurden umverteilt? [online]. Online: https://www.tagesschau.de/ausland/hg-fluechtlingsverteilung-101.html [15.08.2018]

UN (2017). United Nations. 'Famine declared in region of South Sudan - UN' [online]. Online: 
doi: 10.14267/cojourn.2018v3n1a3

http://www.un.org/apps/news/story.asp?NewsID=56205\#.WMkfWBicaV5

[05.04.2018]

UNICEF (2017). 'Famine in East Africa: 5.5 million children in danger' [online]. Online:

https://www.unicef.org.uk/donate/east-africa/ [05.04.2018]

United Nations, Department of Economic and Social Affairs, Population Division (2015).

World Population Prospects: The 2015 Revision. New York: United Nations [online].

Online:https://esa.un.org/unpd/wpp/Publications/Files/Key_Findings_WPP 201

5.pdf [04.04.2018]

UNOCHA (2016). Regional Outlook for the Horn of Africa and the Great Lakes Region.

UNOCHA (2017). EL Niño in East Africa [online]. Online: http://www.unocha.org/legacy/el-nino-east-africa [05.04.2018]

Verisk Maplecroft (2016). 'Climate Change Exposure Index'[online]. Online: https://maplecroft.com/portfolio/new-analysis/2016/12/18/study-africas-

agriculturally-dependent-nations-facing-highest-costs-climate-change-key-agricommodoties-risk [05.04.2018]

Werrell \& Femia (2015). Angle Journal. 'Fragile States. The Nexus of Climate Change, State Fragility and Migration' [online]. Online: https://anglejournal.com/article/2015-11-fragile-states-the-nexus-of-climatechange-state-fragility-and-migration [05.04.2018]

Western D, Mose VN, Worden J, Maitumo, D (2015). Predicting Extreme Droughts in Savannah Africa: A Comparison of Proxy and Direct Measures in Detecting Biomass Fluctuations, Trends and Their Causes. PLoS ONE 10(8): e0136516 [online]. Online: https://doi.org/10.1371/journal.pone.0136516 [05.04.2018]

World Bank (2018). Groundswell: Preparing for Internal Climate Migration [online]. Online: https://openknowledge.worldbank.org/handle/10986/29461 [10.08.2018] FPRI (2014). Building resilience to conflict through food-security policies and programs [online].

Online: http://ebrary.ifpri.org/utils/getfile/collection/p15738coll2/id/128136/filename/12 8347.pdf [05.04.2018] 